\title{
サブピクセル画像処理を用いた構造物の 非接触変形·応力計測法に関する研究”
}

\author{
嘼田道雄 ${ }^{* *} \quad$ 柴原正和 $^{* * *} \quad$ 松石正克 ${ }^{* * *} \quad$ 石川憲一 $^{* *}$ 岩田節雄 $^{\dagger} \quad$ 北村幸嗣 $^{\dagger}$
}

\begin{abstract}
Studies on Non-Contact Deformation and Stress Measurement Technique of Structures using Sub-pixel Image Processing Michio UNEDA, Masakazu SHIBAHARA, Masakatsu MATSUISHI, Ken-ichi ISHIKAWA, Setsuo IWATA and Koji KITAMURA

Strain gauges are frequently used for inspecting the strength and reliability of actual structures. However, the measurement of actual structures by strain gauges needs dangerous works such as pasting strain gauges and cabling them to strain meters located in a remote place. Therefore there is a growing demand for developing non-contact and accurate deformation and stress measuring technique of structures.

The authors developed a non-contact and accurate deformation and stress measuring technique using the sub-pixel digital image processing method. This paper presents the detail of the measuring technique and the method of analyzing the measured data, and the results of performance test of the measurement system. The results of the numerical computation and the experiments demonstrated the effectiveness of our deformation and stress measuring technique using the sub-pixel digital image processing method.
\end{abstract}

Key words: sub-pixel image processing, deformation and stress measurement of structures, non-contact measurement, images correlation, response surface method

\section{1. 緒言}

現在, 鉄筋コンクリートや鉄鋼材料等からなる構造物や, レール等の鉄道構造物に関して, これら構造物の健全性確 保や長期信頼性の保証, 補強・改修必要性の判断を目的と して, 様々な調査や点検が実施されている ${ }^{1)}$. 加えて, 昭和 30 年から 40 年代の高度経済成長期に建設された公共構造物 の供用年数が 40 年近くなった昨今, 維持 - 管理技術の重要 性が増してきている2).

このような維持・管理技術として広く用いられている計 測方法に，ひずみゲージを用いた方法がある．そして，ひ ずみゲージによる方法は, 信頼性の高さに加えて, 計測原 理が簡易であることから一般的に用いられている. しかし， 実構造物の測定現場でひずみゲージを貼り付けるには手間 とコストを要し, 時には作業者が危険な環境に立ち入る必 要もある．また，ゲージの貼り付け位置のひずみ情報しか 得られないことや，取り付けミスが発生する可能性がある こと, 環境によっては測定できないこと, 変形が大きい場 合には測定できないこと等の問題を有している374).このこ とから，ひずみゲージを用いずとも高精度に構造物の変形 や応力状態を計測できる方法の開発が望まれており, 特に 光学的計測法の適用が検討されている.

非接触で且つ, 光学的に計測する有効な方法の一つとし ては, レーザを用いたホログラフィ干渉法がある ${ }^{5)}$. しかし, ホログラフィ干渉法においてはレーザ光源, ミラー, ビー ムスプリッター等の特殊装置を必要とするものであり, 上 記した構造物の計測に適しているとは言い難いと考えられ

* 原稿受付 平成 17 年 6 月 14 日

** 正 会 員 金沢工業大学 (石川郡野々市町扇が丘 7-1)

*** 大阪府立大学 (堺市学園町 1-1)

**** 金沢工業大学 (石川郡野々市町扇が丘 7-1)

† 日立造船株式会社技術研究所（大阪市大正区船町 2-2-11）
る. 一方, デジタルカメラ等のデジタル画像記録機器は飛躍 的に性能が向上し, 近年のコンピュータの発展とともに構 造物のひずみ計測に画像処理を応用する研究が盛んに行わ れるようになっている ${ }^{344) 67)}$.このような中にあって著者ら は, 構造物の変形・応力計測技術に, これまで画像照合と いう異分野で検討されてきた技術としてのサブピクセル画 像処理 ${ }^{879)}$ を用いることによって, 高精度変形・応力計測を 可能にすることを目指して検討を行ってきている.

すなわち, 本研究ではサブピクセル画像処理技術を応用して, 非接触・高精度変形・応力計測法を開発することを目的として いる. 本論文では, サブピクセル画像処理を用いて, 構造物の 変形・応力計測までの一連の解析を行った場合における計測性 能評価に関して, 理想画像を用いた変形・応力計測シミュレー ション，並びに，実験によって本方法の有効性を確認した結果 を述べる.

\section{2. サブピクセル画像処理を用いた変形・応力計測法}

2.1 応答曲面法を用いたサブピクセル変形・応力計測法 画像相関法と応答曲面法を用いた構造物のサブピクセル 変形・応力計測法について, 図1に示すようにX軸方向, $\mathrm{Y}$ 軸方向のピクセルサイズを単位とする長さ $S_{x}, S_{y}$ の(a)変形前 の基準画像及び(b)変形後の計測画像がある場合を例に, そ の概要を述べる.

はじめに, 基準画像, 計測画像におけるピクセル座標計 測点（以下，計測点とする．） $N_{0}(x, y), N_{d 0}(x, y)$ をそれぞれ 計測基準位置とする比較部分画像 $A_{0}(x, y), A_{d 0}(x, y)$ を設定する なお, ここでの比較部分画像 $A_{0}(x, y), A_{d 0}(x, y)$ は取得した基準 画像, 並びに計測画像の一部を, それぞれ計測点 $N_{0}(x, y)$, $N_{d 0}(x, y)$ をその図心として切り出したものであり, 比較部分 画像のX軸方向のピクセルサイズを $d_{x}$, Y 軸方向のピクセル サイズを $d_{y}$ とする. そして, 比較部分画像 $A_{0}(x, y)$ と $A_{d 0}(x, y)$ 


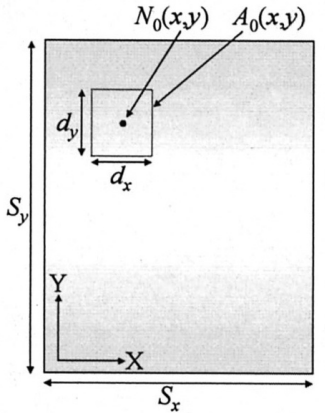

(a) Original image

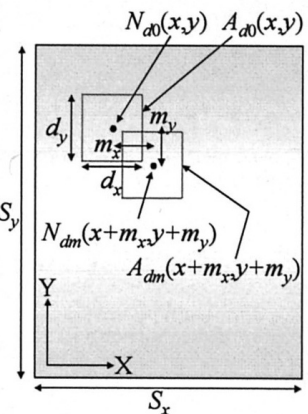

(b) Deformed image
Fig.1 Deformation measurement method by images correlation

の相関值 $r(x, y)$ を求める.

次に, 計測画像中における点 $N_{d 0}(x, y)$ を基準に，その周囲 をX，Y軸方向にそれぞれ1ピクセルを最小変化量として， 例えばX軸及びY軸方向にそれぞれ $m_{x}, m_{y}$ ピクセル変化させ た点 $N_{d m}\left(x+m_{x}, y+m_{y}\right)$ における比較部分画像 $A_{d m}\left(x+m_{x}, y+m_{y}\right)$ を 順次設定する. なお, 点 $N_{0}(x, y)$ や点 $N_{d 0}(x, y)$ の場合と同様に, 点 $N_{d m}\left(x+m_{x}, y+m_{y}\right)$ は比較部分画像 $A_{d m}\left(x+m_{x}, y+m_{y}\right)$ の図心とす る. そして $, m_{x}, m_{y}$ の值をそれぞれ掃引（スキャン）する ことで, 比較部分画像 $A_{0}(x, y)$ と $A_{d m}\left(x+m_{x}, y+m_{y}\right)$ の相関值 $r\left(x+m_{x}, y+m_{y}\right)$ を求める. ここで, $m_{x}, m_{y}$ に関しては, それぞ れで最大值 $\left(m_{x, \max }, m_{y, \max }\right)$, 最小值 $\left(m_{x, \min }, m_{y, \min }\right)$ を有す る整数である. そして, 計測点 $N_{0}(x, y)$ の変形後におけるピク セル単位での移動量（変位量）として，相関值 $r$ の值を極值 とする $m_{x 0}, m_{y 0}$ を求めることになる.

ところで, 相関值 $r$ を極大あるいは極小とするかについて は，使用する相関法に依存するものであり，本論文では残 差自乗和相関を用いた。 したがって, 相関值 $r\left(x+m_{x}, y+m_{y}\right)$ は 式(1)で与えられるとともに, これを最小とする $m_{x 0}, m_{y 0}$ を求 めることになる.すなわち, 残差自乗和相関における相関 值 $r\left(x+m_{x}, y+m_{y}\right)$ は, $A_{0}(x, y)$ と $A_{d m}\left(x+m_{x}, y+m_{y}\right)$ からなる差分行列 の要素自乗和を表す.

$$
r\left(x+m_{x}, y+m_{y}\right)=A_{0}(x, y)-A_{d m}\left(x+m_{x}, y+m_{y}\right)_{2}
$$

なお，記号 \|\|$_{p}$ は行列要素の $p$ 乗和を表すノルムである ${ }^{10)}$. そして, $m_{x 0}, m_{y 0}$ の值は, 基準画像中における計測点 $N_{0}(x, y)$ が計測画像中における点 $N_{d m 0}\left(x+m_{x 0}, y+m_{y 0}\right)$ に移動したとす るピクセル単位での変位計測值を意味するものとなる。

一方, 上記方法で構造物の変形計測を実施する場合, 計 測值の最小分解能は, 当然 1 ピクセルとなる. ところが, 実 構造物の変形計測における分解能としては, 1 ピクセル以下 が要求されることが多いと考えられる.そして，一般に1ピ クセル以下の画像移動量はサブピクセルレベルの移動量と 呼ばれる.このサブピクセルレベルの移動量を検出するた めの方法が, 画像間に変形を伴わない画像照合の分野にお いて検討が進められている.

ここで, 上記サブピクセルレベルの位置ずれを検出する 有効な方法として, 応答曲面を用いた幾つかの方法が提案, 検討されてきている ${ }^{4) 8}$. すなわち，ピクセルレベルで計算 された, 画像相関法に基づく相関面の極近傍を何らかの関 数によって曲面 (応答曲面) 近似を行い, 得られる応答曲 面が極值を示す座標を調べて，その座標からサブピクセル
レベルの位置ずれ量を計測するものである，そこで本論文 においては, 上記応答曲面関数を $g(x, y)$ として, 変数 $x, y$ に 関する次式,

$$
g(x, y)=\alpha_{1} x^{2}+\alpha_{2} y^{2}+\alpha_{3} x y+\alpha_{4} x+\alpha_{5} y+\alpha_{6}
$$

で与えられる2次曲面関数 ${ }^{11)}$ 用いるものとしてサブピクセ ルレベルでの変形計測を実施するものとした. 係数 クセルレベルにおける相関值の極值となる $\left(m_{x 0}, m_{y 0}\right)$ を基準 に, (X軸: $m_{x 0}-1, m_{x 0}, m_{x 0}+1 の 3$ 点) $\times\left(\mathrm{Y}\right.$ 軸 : $m_{y 0}-1, m_{y 0}$, $m_{y 0}+103$ 点 $)=$ 合計 9 点の相関值からなるデータ点集合を用 いての最小自乗法によって求めるものとした. なお, 文献 ${ }^{11)}$ においては適用範囲が変形計測ではないものの, 重回帰分 析で用いられる自由度修正済み決定係数を用いて応答曲面 を決定するために用いるデータ点集合の最適選択方法につ いて検討されているが, 本論文においては前述の方法のよ うに最適選択までは実施していないことを付記する.

\section{2 サブピクセルレベル変形計測値を用いた応力解析法}

前節の方法によって求められた変位計測值を用いて応力 を計算することは, 次の方法によって可能になると考えら れる. すなわち, 基準画像中における応力計測の要素は, $\mathrm{X}$ 軸方向に $p_{x}, \mathrm{Y}$ 軸方向に $p_{y}$ となる方形であると仮定する。 そ して, 基淮画像中における計測点 $N_{0}(x, y)$ に対して, X軸方向 およびY軸方向において, 隣り合う計測点を $N_{1}\left(x+p_{x}, y\right)$, $N_{3}\left(x, y+p_{y}\right)$ とするとともに，対角上にある計測点を $N_{2}\left(x+p_{x}, y+p_{y}\right)$ として考えると, これら4つの計測点からなる 要素によって, 応力解析を実施することができる.この場 合, これら4つの計測点 $N_{i}(x, y) \quad(i=0 \sim 3)$ が, $\mathrm{X}$ 軸方向, $\mathrm{Y}$ 軸方向にそれぞれ， $u_{i}, v_{i}$ 移動したと考える.このとき，こ れら 4 計測点からなる要素中心点 $N_{c 0}\left(x+p_{x} / 2, y+p_{y} / 2\right)$ が変形後 に生じるX軸方向ひずみ，Y軸方向ひずみ，剪断ひずみ，並 びに, X軸方向応力, $\mathrm{Y}$ 軸方向応力, 剪断応力をそれぞれ, $\varepsilon_{x}\left(x+p_{x} / 2, y+p_{y} / 2\right), \varepsilon_{y}\left(x+p_{x} / 2, y+p_{y} / 2\right), \gamma_{x y}\left(x+p_{x} / 2, y+p_{y} / 2\right)$, 並びに, $\sigma_{x}\left(x+p_{x} / 2, y+p_{y} / 2\right), \quad \sigma_{y}\left(x+p_{x} / 2, y+p_{y} / 2\right), \quad \tau_{x y}\left(x+p_{x} / 2, y+p_{y} / 2\right)$ とする と, これらの值は簡易的に,

$$
\begin{aligned}
& \varepsilon_{x}\left(x+\frac{p_{x}}{2}, y+\frac{p_{y}}{2}\right)=\frac{\left(u_{1}+u_{2}\right)-\left(u_{0}+u_{3}\right)}{2 p_{x}} \\
& \varepsilon_{y}\left(x+\frac{p_{x}}{2}, y+\frac{p_{y}}{2}\right)=\frac{\left(v_{2}+v_{3}\right)-\left(v_{0}+v_{1}\right)}{2 p_{y}} \\
& \gamma_{x y}\left(x+\frac{p_{x}}{2}, y+\frac{p_{y}}{2}\right)=\frac{u_{3}-u_{0}}{2 p_{y}}+\frac{v_{1}-v_{0}}{2 p_{x}}+\frac{v_{2}-v_{3}}{2 p_{x}}+\frac{u_{2}-u_{1}}{2 p_{y}}
\end{aligned}
$$

$\left(\begin{array}{c}\sigma_{x}\left(x+\frac{p_{x}}{2}, y+\frac{p_{y}}{2}\right) \\ \sigma_{y}\left(x+\frac{p_{x}}{2}, y+\frac{p_{y}}{2}\right) \\ \tau_{x y}\left(x+\frac{p_{x}}{2}, y+\frac{p_{y}}{2}\right)\end{array}\right)=\frac{E}{1-v^{2}}\left(\begin{array}{ccc}1 & v & 0 \\ v & 1 & 0 \\ 0 & 0 & \frac{1-v}{2}\end{array}\right)\left(\begin{array}{c}\varepsilon_{x}\left(x+\frac{p_{x}}{2}, y+\frac{p_{y}}{2}\right) \\ \varepsilon_{y}\left(x+\frac{p_{x}}{2}, y+\frac{p_{y}}{2}\right) \\ \gamma_{x y}\left(x+\frac{p_{x}}{2}, y+\frac{p_{y}}{2}\right)\end{array}\right)$

として求めることができる.なお，Eは測定対象物の縦弾性 係数, vはポアソン比である. すなわち, 上式を用いること によってサブピクセルレベルでの変位計測值に基づいて応 力解析を行うことができる.

\section{3. 理想画像を用いたサブピクセル変形・応力計測法に関 する性能評価シミュレーション}

前章までの計測法を基に，本章では単純一軸引張りによ 


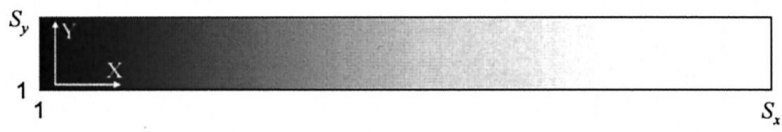

Fig.2 Idealized image for computation

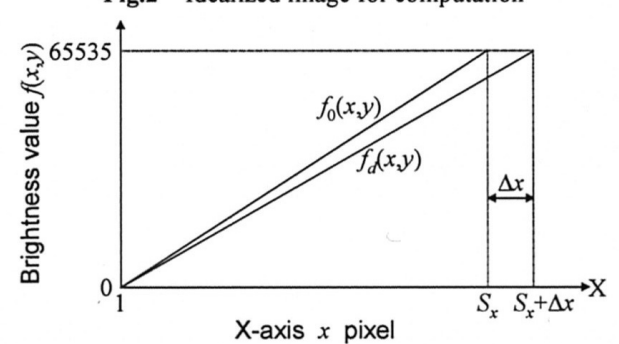

Fig.3 Brightness values of both original image and deformed image for computation

って生じる画像変形をモデル化し，その変形・ひずみ計測 を実施することによって，本研究で提案するサブピクセル 変形・応力計測法の精度を検証する．なお，本シミュレー ションは理想画像を作ることによってサブピクセル方法の 精度限界に及ぼす画像特有の階調度, いわゆるbit数に起因 した画像輝度值の分解能の影響を知ることを目的にして行 ったものである.

\section{1 変形前後における画像のモデル化}

ここでは，図2に示すような（変形前）画像を検討対象と して議論を進める. 基準画像, 並びに計測画像のサイズは, $\mathrm{X}$ 軸 : $S_{x}$ ピクセル, $\mathrm{Y}$ 軸 : $S_{y}$ ピクセルとした。 また, 各ピク セルにおける輝度值を0〜65535での整数で表現した。すな わち，本検討では，16bit画像をモデル化している．このと き，Y軸方向での輝度值はすべて同一であるとし，X軸方向 への輝度值の変化は，図3に従うと仮定する．このとき，基 準画像におけるX軸方向に $x$ ピクセル, Y軸方向に $y$ ピクセル での輝度值 $f_{0}(x, y)$ は,

$$
f_{0}(x, y)=R\left[\frac{65535}{S_{x}-1}(x-1)\right]
$$

となる. なお, $x$ は $1 \sim S_{x}, y$ は $1 \sim S_{y}$ 間の自然数であり,$R[\cdot]$
は小数点第1位を四捨五入する処理を表すものとする.

次に, 計測画像（変形後画像）を，図2の基準画像（変形 前画像）に対して, X軸方向に $\Delta x$ の伸びを生じた場合として 考える. このとき, 計測画像における輝度值 $f_{d}(x, y)$ は,

$$
f_{d}(x, y)=R\left[\frac{65535}{S_{x}-1+\Delta x}(x-1)\right]
$$

として与えられ，それは図3に示したようになる.

\section{2 サブピクセル変形・応力計測法の精度検証}

図4(a)は， $S_{x}$ を1001ピクセル， $S_{y}$ を201ピクセルとし，変形 量 $\Delta x$ を 3 ピクセルとした場合, すなわち, 画像間の変形に伴 うX軸方向のひずみ 変位計測点 $x$ と変位計測值, 並びに, 理論変位量の関係を示 している，また，同図(b)は変位計測值と理論変位量との間 で生じる変位計測誤差の分布を示している，なお，本シミ ユレーションの場合における $x$ ピクセルでの理論変位量と は, 画像に階調制限を設けない場合として, その值は, $\varepsilon(x-1)$ で与えられる。一方, 比較部分画像のサイズとしては, $d_{x}=d_{y}=S_{y}$ とした．したがって，相関值の掃引はX軸方向のみ としたため, 式(2)で与えた応答曲面関数においても，この 場合はX軸方向のみの変化を取り扱った．また，同図(c)は同 図(a)のサブピクセル変形計測值を用いて，ひずみ計測（計 算）を行った結果である．なお，X軸方向ひずみ $\varepsilon_{x}(x, y)$ を求 めた.

この結果から，変位計測值は理論変位量と同等の結果て

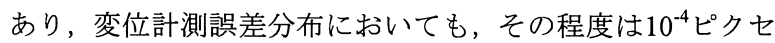
ルオーダであり，かなりの高精度で計測できていることが 分かる. 一方, この変位計測值に基づいてひずみ計測を行 ったところ，同図(c)から， $\pm 100 \mu( \pm 0.0001)$ 程度のひず み計測誤差があることが分かる.

ここで，このように変位・ひずみの計測值に対して誤差 を生じる理由としては，階調制限に起因した誤差の丸めこ みがあると考えられる。 すなわち，今回のシミュレーショ ンにおいては階調制限画像を作るにあたり，式(5)，(6)に示 したように，小数点以下情報の四捨五入による丸めこみを 行ったが，この際に隣接するピクセル間同士で類似の丸め

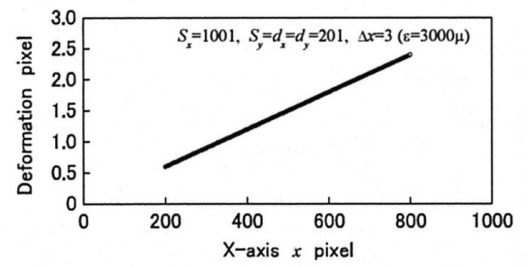

(a) Relationship between measuring point $x$ and measured deformation value

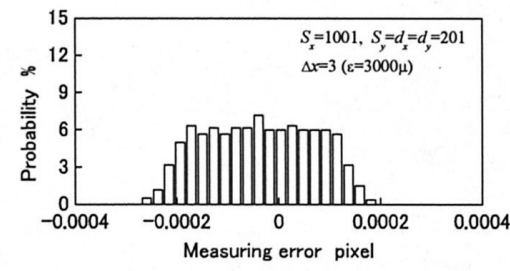

(b) Distribution of measuring error between measured and theoretical deformation value

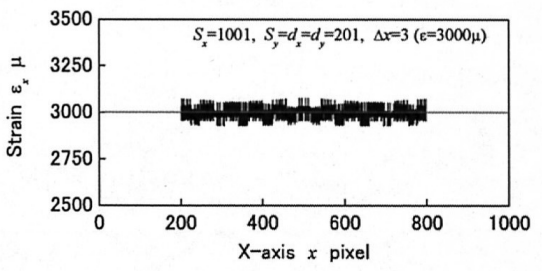

(c) Relationship between measuring point $x$ and measured strain value

Fig.4 Computation results of deformation and strain measurement value at $\left(d_{x}, d_{y}\right)$ values of 201 and $\varepsilon$ of $3000 \mu$

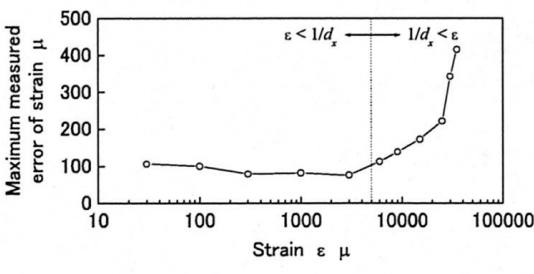

Fig.5 Effect of image strain on maximum measured error of strain

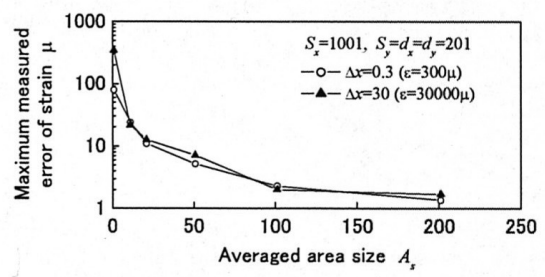

Fig.6 Decreasing of maximum measured error of strain by averaging processing of measured strain value 


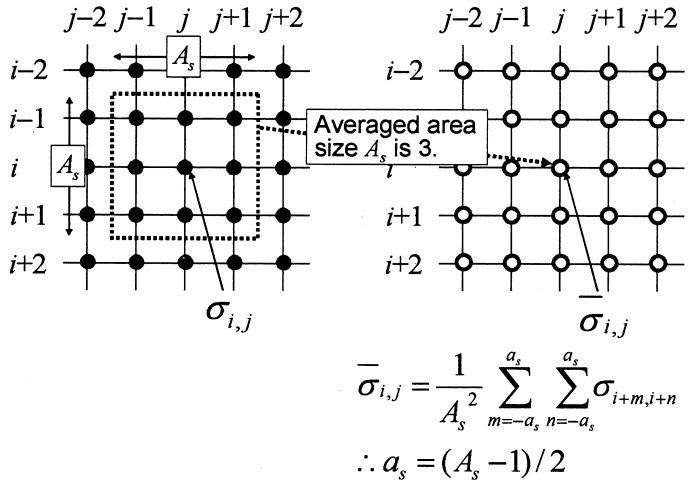

Fig.7 An example of mean stress averaged over $3 \times 3$ measurement points

こみが行われたことで，画像情報が階段状になったことが 原因と考えられる．すなわち，理想画像におけるシミュレ ーションにおいて当該事項を原因とする誤差を生じること から, 本結果は実際に取得される画像の解析においての精 度限界の指針を与えるものであると考えられる。

図5は画像に生じたひずみが，ひずみ計測值の誤差分布に 及ぼす影響を検討した結果である．なお，誤差分布として はひずみ計測における最大誤差值で評価した。この結果よ り，画像のひずみが $1 / d_{x}$ 以下である場合には誤差分布はほ ぼ一定であることに対して，画像のひずみが $1 / d_{x}$ 以上とな る場合には誤差分布は急増していることが分かる.すなわ ち, 画像のひずみが $1 / d_{x}$ 以上となる場合, 基準画像におい て1〜 $d_{x}$ ピクセル内に含まれていた画像情報が, 計測画像に

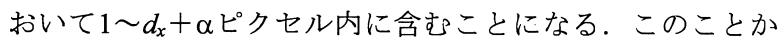
ら, 変形計測における誤差が増加することによって, この ような結果になるものと考えられる.

このようにして生じるひずみ計測值の誤差を低減する有 効な方法として, 近傍計測点同士0平均化処理があると考 えられる. 図6はひずみの誤差分布低減に与える平均化処理 サイズの影響を示している．なお，ここでの平均化処理は 図7に示すように, 各計測点で計測された応力值に対しての 平均化処理を意味している. 寸なわち, 図7では平均化処理 サイズ $A_{s}$ が3である場合を一例として模式的に示しているが, 平均化処理前に計測点 $N(i, j)$ で得られる応力值 $\sigma_{i, j}$ を平均化 処理後に $\bar{\sigma}_{i, j}$ と置き換えることになる. 図6に示すように, 平均化をしない場合（同図横軸の平均化処理サイズ $A_{s}$ が1の 場合）の誤差分布に比較して，平均化処理を行うことによ って誤差分布は大きく低减できていることが分かる．加え て，平均化をしない場合には図5に示したように画像に生じ たひずみの大小がひずみ計測精度に及ぼす影響は大きく， それは図60平均化処理サイズが1である場合の結果ふらも 見受けられる. 一方, 平均化処理を行うことによって画像 のひずみによる精度の相違は殆ど無いことが分かる．この ことから，平均化処理によってひずみ計測精度を向上する ことができると言える.

したがって，画像による構造物の変形・ひずみ計測を行 う場合, 画像の階調制限に起因寸る誤差要因の影響等を受 けることになるが，それを低減するためには平均化処理が 有効な方法であると考えることができる.

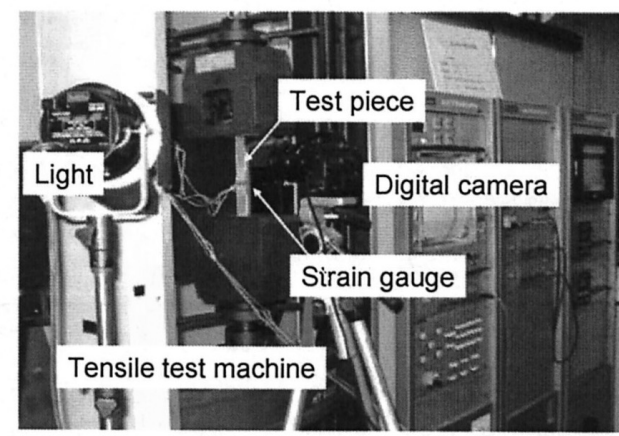

Fig.8 Experimental set-up configuration

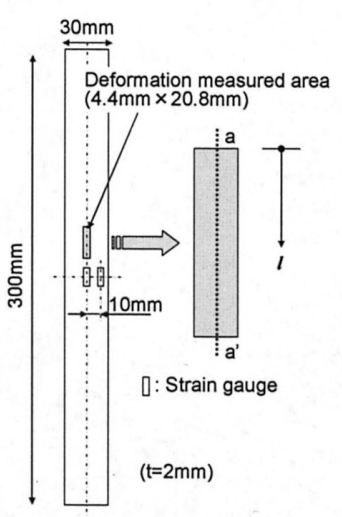

(a) Without hole

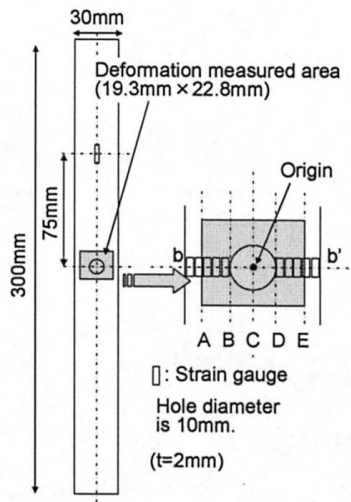

(b) With hole
Fig.9 Detail of test-piece

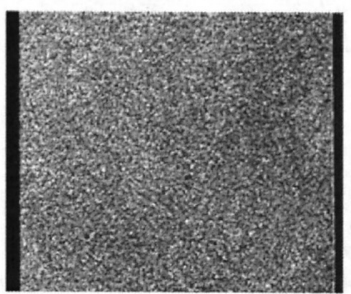

(a) Appearance

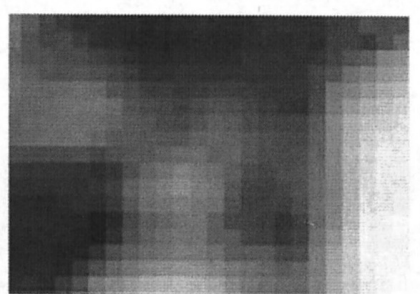

(b) Magnified photograph
Fig.10 An example of surface of test-piece

\section{4. 実験による性能検証}

\section{1 実験方法}

実験は図8のような状況で行った。すなわち, 引張試験機 によってアルミ（A5052-O, 縦弾性係数 $E=69.3 \mathrm{GPa}$, ポアン ン比 $v=0.3 ）$ 製の帯板, 並びに円孔板試験体の引張試験を行 い, その引張りによって各試験体に生じる変形量, 並びに ひずみ量をサブピクセル画像処理によって計測するという ものである. なお, 使用した引張試験機は上部チャックが 固定され，下部チャックが下方に移動するものである.

試験体は図9のような形状であり，同図(a)が帯板試験体， 同図(b)が円孔板試験体である.ここで, 実験で用いたアル ミ板には, 図10のようにスプレー塗料による微小特徽の付 与を行っている ${ }^{12)}$. 図10(a)は幅 $30 \mathrm{~mm}$ のアルミ板の外観であ り, 図10(b)はピクセルによる格子模様が分かるまでに図 10(a)の一部を拡大した写真である. すなわち, 元々のアル ミ材には光沢が有り, (1)実構造物の表面性状を考えての防 
Table 1 Analysis cases of deformation and stress measurement (a) Without hole (Case I)

\begin{tabular}{l|l}
\hline Original image & $\varepsilon_{a}=0 \mu$ \\
Case I-1 & $\varepsilon_{a}=349 \mu(337 \mu, 338 \mu, 364 \mu, 357 \mu)$ \\
Case I-2 & $\varepsilon_{a}=595 \mu(576 \mu, 577 \mu, 619 \mu, 608 \mu)$ \\
Case I-3 & $\varepsilon_{a}=961 \mu(932 \mu, 934 \mu, 998 \mu, 982 \mu)$ \\
\hline
\end{tabular}

(b) With hole (Case II)

\begin{tabular}{l|l}
\hline Original image & $\varepsilon_{a}=0 \mu$ \\
Case II-1 & $\varepsilon_{a}=231 \mu(230 \mu, 231 \mu)$ \\
Case II-2 & $\varepsilon_{a}=465 \mu(461 \mu, 468 \mu)$ \\
Case II-3 & $\varepsilon_{a}=710 \mu(703 \mu, 716 \mu)$ \\
\hline
\end{tabular}

Notes: $\varepsilon_{a}$ means average value. Numerical values in parenthesis are measured values by each gauge

錆塗料を模擬すること，(2)本計測方法では光沢面計測は困 難であると考えられること，を考慮してスプレー塗料の付 与を行った.

各試験体には，それぞれ図9中のように所定の位置にひず みゲージが貼り付けられている，なお，写真撮影面を表と して, 帯板試験体は表裏各2枚の計4枚, 円孔板試験体には 円孔 $75 \mathrm{~mm}$ 上部は表裏各1枚, 円孔部は裏面のみ 10 枚の計 12 枚のひずみゲージが張られている．そして，これらゲージ 出力を画像処理によって計測した変形・応力值との比較用 データとして用いた.

帯板試験体の場合における変形計測値は, ひずみゲージ からの出力值に対しての比較データとして, ゲージ出力で あるひずみとから得られる伸び $\Delta l を$

$$
\Delta l=d
$$

として求めた. lはY軸方向における図9(a)中の点aを基準と した計測座標である.

画像の取得には階調制限が16bitであり，また，1200万ピ クセルの解像度を有する一眼レフレンズ対応のデジタルカ メラを使用しており, 本実験によって得られた画像1ピクセ ルのサイズは約 $11.3 \mu \mathrm{m}$ である. なお, 変形計測・応力解析 を実施した場所は図9における長方形で示した部分であり, 計測に使用した画像としては，表1に示すように，(a)帯板試 験体（Case I），(b)円孔板試験体（Case II）ともに1つの基 準画像に対して, 3つ（1～3）の計測画像の変形・応力を解 析した. なお, 同表(b)中の值は, 円孔上部 $75 \mathrm{~mm}$ の部分の表 裏に張られたひずみゲージの出力である. また, 応力解析 を実施する場合には, 平均化処理を行うものとし, 平均化 処理サイズ $A_{s}$ は21とした。

\section{2 帯板試験体の場合}

図11は帯板試験体の場合において, 図9(a)中a-a'線上の変 位をサブピクセル画像処理によって計測された結果とひず みゲージの出力值から計算した変位の関係を示している. この結果から, 計測される変位はひずみゲージの出力結果 と同等の精度を有していることを確認することができる．

図12はサブピクセル画像処理によって計測された変位の 結果に基づいて, 式(3), (4)を用いて計測面全面における応 力分布を計算した結果であり，ある程度の誤差を有するも のの, 一様応力状態であることを計測できていることが分 かる、また, 図13は計測領域の中心線（図9(a)中a-a'線）上 における応力分布を示した結果であり,この結果から, \pm $10 \mathrm{MPa}(\fallingdotseq \pm 100 \mu$ ひずみ）の精度で応力を計測できている ことが分かる.

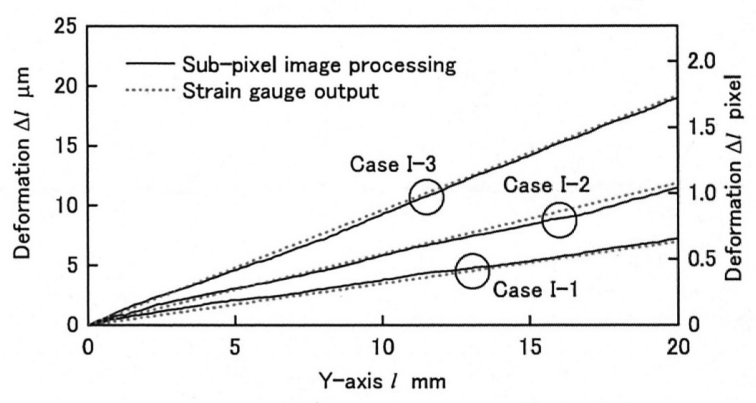

Fig.11 Comparison between measuring result of relative deformation value by sub-pixel image processing and calculated result by strain output along a-a' line

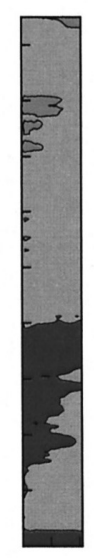

(a) Case I-1

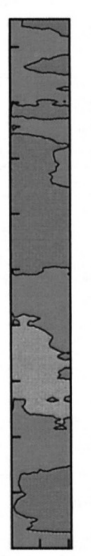

(b) Case I-2

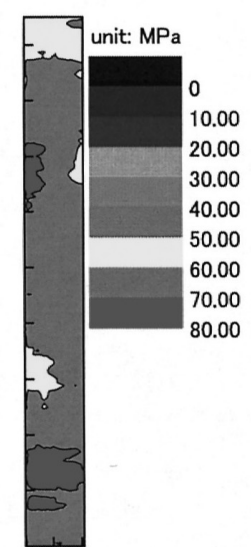

(c) Case I-3
Fig.12 Contour diagrams of stress distribution at cases of without hole

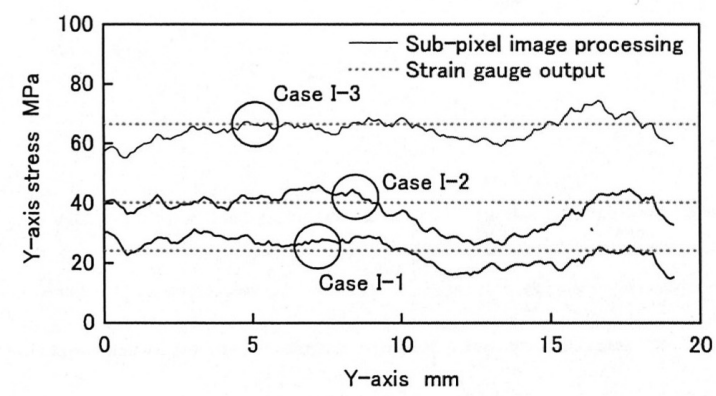

Fig.13 Comparison between measuring results of stress value by sub-pixel image processing and results by strain output along a-a' line

\section{3 円孔板試験体の場合}

図14は円孔板試験体の場合において, サブピクセル画像 処理で計測された変位を示している，なお，計測線として は, 図9(b)中のA〜Eの各線上の変位を示した．また，円孔 中心を解析上の座標原点としている.この結果から, 試験 体の両端部（A線，E線）付近においては，ほぼ一様の傾斜 で変位が増加していることに対して, 最も応力集中を生じ る部分である円孔側部（B線，D線）においては，円孔付近 においての変位の傾きが大きくなっていることが分かる. このことは，応力集中を生じていることが計測できている ことを示唆するものである. 一方, 中心部 (C線) において は, 円孔上部, 下部のそれぞれにおいて, 変位の変化は殆 


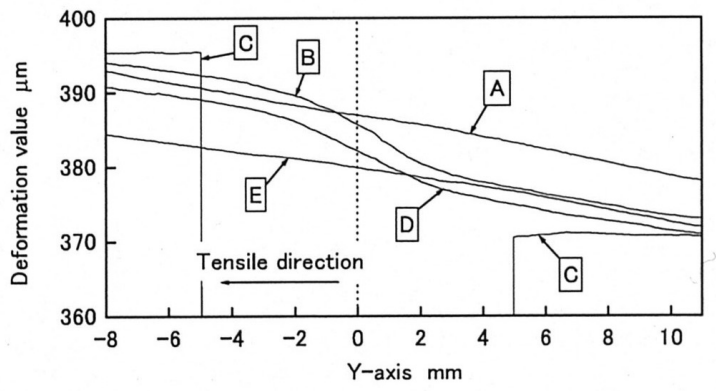

Fig.14 Measuring results of deformation values by sub-pixel image processing by strain output along A to $\mathrm{E}$ lines at case II-3

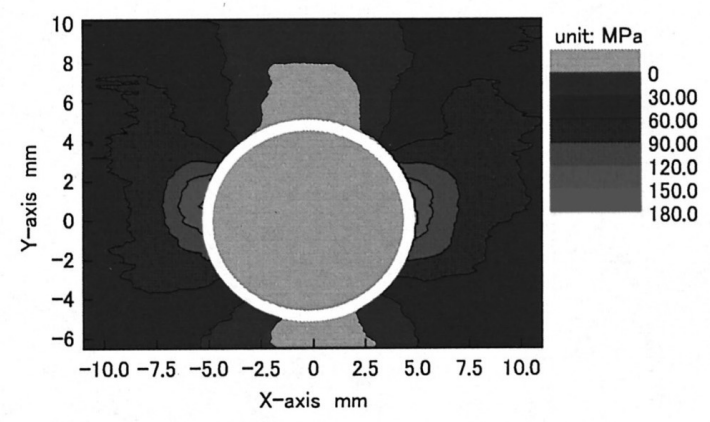

Fig.15 Contour diagrams of stress distribution at case II-3

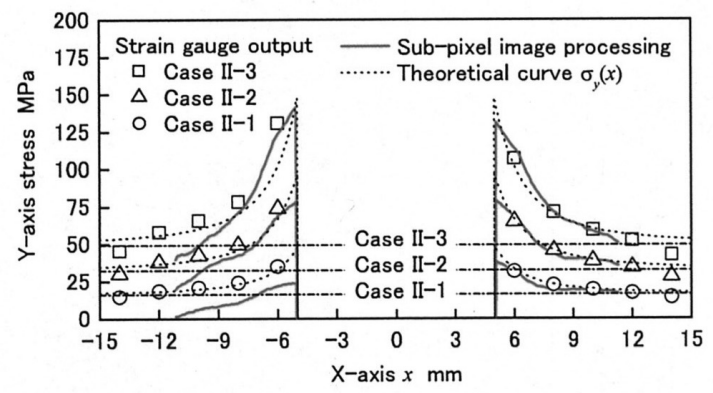

Fig.16 Comparison between measuring results of stress value by sub-pixel image processing and results by strain output along b-b' line at cases of with hole

ど見受けられないことから, 応力が小さいということが予 想され，これは，理論通りの結果であると言える.

図15は上記を含めた変位の計測結果に基づいて, 計測領 域全面における応力分布を計算した結果である.この結果 から，円孔側部において応力集中を生じているとともに， 円孔上部，下部においての応力が小さくなっていることが 分かる.

図16は円孔断面部においてサブピクセル画像処理によっ て計測された応力分布（実線），並びに，ひずみゲージに よって計測された応力 (プロット) を比較した結果である. また, 同図中の1点鎖線（水平線）は表1(b)中に示した円孔 上部 $75 \mathrm{~mm}$ の位置にあるひずみゲージ出力から計算した円 孔遠方部での応力 $\sigma_{0}$ である. これらに加えて, 式(8)によっ て与えられる一様引張を受ける円孔の応力分布を計算した 結果を図16中の点線で示す.

$$
\sigma_{y}(x)=\sigma_{0}\left(1+\frac{r^{2}}{2 x^{2}}+\frac{3 r^{4}}{2 x^{4}}\right)
$$

なお， $\sigma_{0}$ は上記で求めた円孔遠方部の応力であり，rは円孔
半径 $(=5 \mathrm{~mm})$ である.この結果から, 円孔左側においては 幾分の差違が見受けられるが, 全体としては, サブピクセ ル画像処理による計測值, ひずみゲージによる計測值, 並 びに, 式(8)による理論值はほぼ同程度の結果であることが 分かる.

したがって，以上の結果から，本研究で検討しているサ ブピクセル画像処理を用いた計測法は, 構造物の変位のみ ならず，変位の計測結果に基づいた応力計測も可能にする 技術であることを実験からも確認することができた．特に， 本論文では式(2)で与えた応答曲面関数の最適化等について の検討を行っていないものの，実験結果に見られる精度が 得られていることから，本近似の有効性を実験的に示すこ とができたと考えられる.

\section{5. 緒言}

本研究では, サブピクセル画像処理を用いた, 構造物の非接 触・高精度変形・応力計測法を開発することを目的としている. 本論文では, 本方法を用いての変形計測精度, 並びに, 応力計 測精度に関して, 理想画像を用いたシミュレーション, 並びに, 実験の両面から検証した。ここでは, 本論文で得られた結果を 要約し, 以下にまとめる.

（1）サブピクセル画像処理を用いることで, サブピクセルレ ベルでの変形計測が可能になる.

(2) サブピクセル変形計測值に基づいて応力計測を実施する 場合, 変形計測精度に起因した応力計測值の誤差を生じ る. また, 平均化処理をすることによって, 応力計測誤 差の低減, 並びに, 高精度応力計測を可能にする.

(3) 本計測方法について実験的にも検証したが，一様応力の みならず, 応力集中を生じる状態であっても, ひずみゲ ージと同等レベルの応力計測を可能にする.

\section{文 献}

1) 山田 徹, 桑原清, 渡辺泰孝, 挂橋孝夫 : デジタルビデオ画像を用 いた軌道変位計測, 土木学会第 58 回年次学術講演会, (2002) 141 .

2) 堀井千絵, 中村秀治, 藤井 堅 : 画像計測における標点の読み取り 方法について, 土木学会第 58 回年次学術講演会, (2002) 887.

3）酒井理哉, 宮川義範, 松尾豊史, 末広俊夫, 遠藤達巳 : 画像計測を 利用した鉄筋コンクリート構造のひずみ計測, 土木学会第 56 回年 次学術講演会講演論文集, (2001) 164.

4) 西田 昇, 田代発造, 廣瀬智博, 野村 俊, 神谷和秀, 園田里見: 二 次元サブピクセル画像処理による木材パネルのひずみ測定, 2003 年精密工学会秋季大会学術講演会講演論文集, (2003) 484.

5) I.Takahashi, T.omura, Y.Morimoto, S.Yoneyama, and M.Fujigami : Deformation measurement by digital holography interferometry, Proc. SPIE Int. Soc. Opt. Eng., 5264 (2003) 206.

6) 舘石和雄, 判治 剛 : 画像計測によるひずみ制御低サイクル疲労試 験, 土木学会第 58 回年次学術講演会講演論文集, (2003) 129.

7) 佐藤秀人, 国府田 誠, 田村昌仁, 刑部 徹, 和田昇三, 酒井茂賀, 熊田哲規: デジタルカメラによるコンピュータ画像計測法に関する 研究一アルミ棒積層体を用いた模型実験の計測システム一, 日本建 築学会構造系論文集, 565，95-101 (2003) 95.

8）荻原瑞木，川又政征 : 位相限定相関を用いた画像のサブピクセル精 度の位置ずれ検出, 電子情報通信学会技術研究報告, (2001) 79 .

9）村瀬一朗，金子俊一，五十嵐 悟：増分符号相関による画像照合 光沢物体および不良照明条件に対するロバスト画像処理一, 精密工 学会誌, 66, 2 (2000) 261.

10) Gene H. Golub, Charles F. Van Loan : MATRIX COMPUTAIONS, The Johns Hopkins University Press, (1983) 12.

11）稲田貴臣, 島村佳伸, 章, 小林英男, 中村春男 : 応答曲面法を 用いた固有振動数変化による CFRP 積層梁の損傷同定, 日本機械学 会論文集（A 編），65，632(1999) 776.

12）野村 俊, 神谷和秀, 佐久間映一, 田代発造: デジタル画像処理に よる木材の変位測定に関する研究〜ランダムパターン製作装置の 開発とその評価〜, 2005 年度精密工学会春季大会学術講演会講演論 文集, (2005) 375 . 